\title{
Isolation of atmospheric nitrogen-free fixing bacteria from the endorhizosphere of Helianthus tuberosus and Smallanthus sonchifolius
}

\begin{abstract}
The objective of the work was to determine the presence of fixing bacteria free of atmospheric nitrogen in the endorhizosphere of topinambur (Helianthus tuberosus) and yacón (Smallanthus sonchifolius), cultivated in the Central Valley of the Province of Catamarca. Roots of each species were collected and the technique proposed by Döbereiner et al. ${ }^{1}$ for the isolation of $\mathrm{N}$-free endorrhizospheric fixing bacteriatwo, Azospirillum sp. The isolates obtained were morphologically and physiologically characterized, and three different morphotypes of each plant species were selected for molecular identification. Eleven autochthonous fixative microorganisms free of atmospheric nitrogen present in the endorhizosphere of the crops under study were described, 6 in topinambur and 5 in yacón. All isolates belonging to the genus Pseudomonas. In topinambur, Pseudomonas sihuiensis and in yacón of Pseudomonas alcaligenes, P. resinovorans and P. sihuiensis. The isolation of autochthonous nitrogen-free bacteria native to P. sihuiensis, P. alcaligenes and P. resinovorans is reported for the first time in the endorhizosphere of topinambur (H. tuberosus) and yacón (S. sonchifolius), cultivated in soils of the Central Valley of the Province of Catamarca.
\end{abstract}

Keywords: jerusalem artichoke, yacón, catamarca, diazotrophs, pseudomonas
Volume 4 Issue 4 - 2020

\author{
Di Barbaro Gabriela,' Del Valle, Eleodoro, ${ }^{2,3}$ \\ Brandán de Weht Celia ${ }^{4}$ \\ 'Faculty of Agricultural Sciences, National University of \\ Catamarca. Avda. Belgrano and Maestro Quiroga, Argentina \\ ${ }^{2}$ Faculty of Agrarian Sciences, National University of the Littoral, \\ Argentina \\ ${ }^{3}$ National Council for Scientific and Technical Research, \\ Argentina \\ ${ }^{4}$ Faculty of Agronomy and Zootechnics, National University of \\ Tucumán, Argentina
}

\begin{abstract}
Correspondence: Di Barbaro Gabriela, Faculty of Agricultural Sciences, National University of Catamarca. Avda. Belgrano and Maestro Quiroga,Argentina,

Email gabydibarbaro@yahoo.com.ar
\end{abstract}

Received: July 0I, 2020 | Published: August 04, 2020

\section{Introduction}

Molecular nitrogen (N2) that exists in the atmosphere is not easily assimilated by plants because the triple bond that unites the atoms that make up the molecule is difficult to break; plants then take advantage of atmospheric nitrogen through the metabolic process known as Biological Nitrogen Fixation $(\mathrm{FBN}){ }^{2}$ This process is carried out by certain soil microorganisms known as "nitrogenfixing microorganisms" that convert nitrogen (Nt2) in ammonia (NH3) through the enzymatic complex called nitrogenase. ${ }^{3}$ Nitrogenfixing microorganisms include symbiotic nitrogen-fixing fixers in association with plants, and free-living microorganisms that provide nitrogenous compounds for use by plants. ${ }^{4}$

Biological nitrogen fixation is the main source of this element to natural ecosystems and to agro-ecosystems without chemical fertilization, ${ }^{2,5,6}$ where this process contributes approximately 140 million tons of nitrogen per year, becoming the main entry of this element into the biosphere. ${ }^{3}$ By fixing nitrogen, these microorganisms influence the productivity of the crops and part of it is available in the soil as a carbon source for its microflora ${ }^{2,6}$ Among the genera of free-living FBN bacteria are Azomonas, Azospirillum, Azotobacter, Beijerinckia, Burkholderia, Clostridium, Derxia, Desulfovibrio, Enterobacter, Herbaspirillum, Klebsiella, Paenibacillus and Pseudomonas. ${ }^{7}$ However, the main free-fixing $\mathrm{N}$-fixing microorganisms constituting the main biofertilizers correspond to the genera: Achromobacter, Acetobacter, Alcaligenes, Arthrobacter, Azotobacter, Cyanobacteria, Azospirillum and Pseudomonas. ${ }^{6,7}$

Due to their ability to fix nitrogen, nitrogen fixing bacteria are considered as candidates for the production of biofertilizers, which are manufactured in various countries of the world. Currently, biofertilizers are considered an important biotechnological tool, which consists in applying microorganisms that They help improve the availability of nutrients in the soil and thus reduce the effects caused by excess fertilizers. The use of biofertilizers in different crops has shown positive effects on soil fertility. ${ }^{6}$

Topinambur (H. tuberosus) and yacón (S. sonchifolius) crops date back to pre-Columbian times and have long been restricted to very small areas as they are adapted to ecological conditions in the Andes, where their use is strongly linked to the traditions of the peoples, ${ }^{8}$ and in recent years has gained great interest for its nutraceutical properties.

The consumption of foods with physiological and biochemical benefits are increasing, which is why the production of topinambur and yacón has generated interest in the last decade. Topinambur and yacón are perennial herbaceous plants that have sweet-tasting tuberous roots and are native to South America, where it is used in human food and in folk medicine for the treatment of diabetes, digestive problems, constipation and other diseases. ${ }^{9,10}$ These tubers contain natural antioxidants, fructans and fructooligosaccharides of interest to the nutraceutical industry. ${ }^{10,11-13}$

The H. tuberosus crop has a wide worldwide distribution. It is cultivated in various countries of the world, such as Italy, Australia, ${ }^{14}$ Germany, ${ }^{15}$ Austria, the Czech Republic, ${ }^{16}$ Denmark, ${ }^{17}$ Poland, ${ }^{18}$ Serbia, ${ }^{19}$ China, ${ }^{20}$ South Korea, ${ }^{21,22}$ Japan, ${ }^{23}$ Thailand, ${ }^{24}$ the United States, ${ }^{25} \mathrm{Cuba}^{26}$ and Brazil. ${ }^{27}$ However, in the country there are references to some dispersed producers in the provinces of Buenos Aires, Córdoba, Entre Ríos, Mendoza, Río Negro, Chubut and San Luis. ${ }^{28}$

While, S. sonchifolius is currently distributed throughout a large part of the Andean territory from northern Ecuador to northwestern Argentina ${ }^{29,30}$ and has been successfully cultivated in several regions, including: Brazil, Czech Republic, China, Korea, Japan, New Zealand, 
Russia, Taiwan and the United States., ${ }^{9,31-33}$ In Argentina, yacón is only cultivated in the provinces from Jujuy, Salta and Tucumán. ${ }^{34,35}$ In Catamarca, both topinambur and yacón are non-traditional crops in the province and have been produced by a single producer in the area.

The objective of the work was to determine the presence of atmospheric $\mathrm{N}$-free fixing bacteria in the endorhizosphere of topinambur and yacón plants in the province of Catamarca.

\section{Materials and methods}

Specimens of topinambur (H. tuberosus) and yacón ( $\mathrm{S}$. sonchifolius) were collected from different bioassays that were carried out in the Central Valley of the Province of Catamarca at $\left(28^{\circ} 28^{\prime} 07^{\prime \prime} \mathrm{LS} 65^{\circ} 46^{\prime} 60^{\prime \prime} \mathrm{LO}\right)$, place which is immersed in the semiarid region of the northwest of the Argentine Republic.

Isolations of atmospheric $\mathrm{N}$-free fixing bacteria from the endorhizosphere of topinambur and yacón plants were performed according to the procedure described by Döbereiner et al. ${ }^{1}$ in which the semi-solid and RC NFb culture media were used. ${ }^{1,36}$ For the identification of the isolated bacteria, the morphological, physiological and biochemical characters were established and examined according to the methods described by Holt et al. ${ }^{37}$ and Buchanan et al. ${ }^{38}$ For each isolate, the color of the colonies was determined in specific culture media (RC); morphology of the observed colony; response to Gram Nicolle and Shaffer and Fulton staining; acid/alkali production (semisolid $\mathrm{NFb}$ with bromothymol blue as indicator) and assimilation tests using different carbon sources (glucose, lactose, malic acid and starch). The tests of each bacterial isolate were carried out in triplicate (Figure 1).

For molecular identification, the isolates were sent to the Macrogen company (Korea), who were responsible for the extraction, amplification and sequencing of the DNA of each strain, and the bioinformatic analysis, which consisted of the analysis of the sequences obtained in the search for similar sequences in the GenBank through the BLAST program.

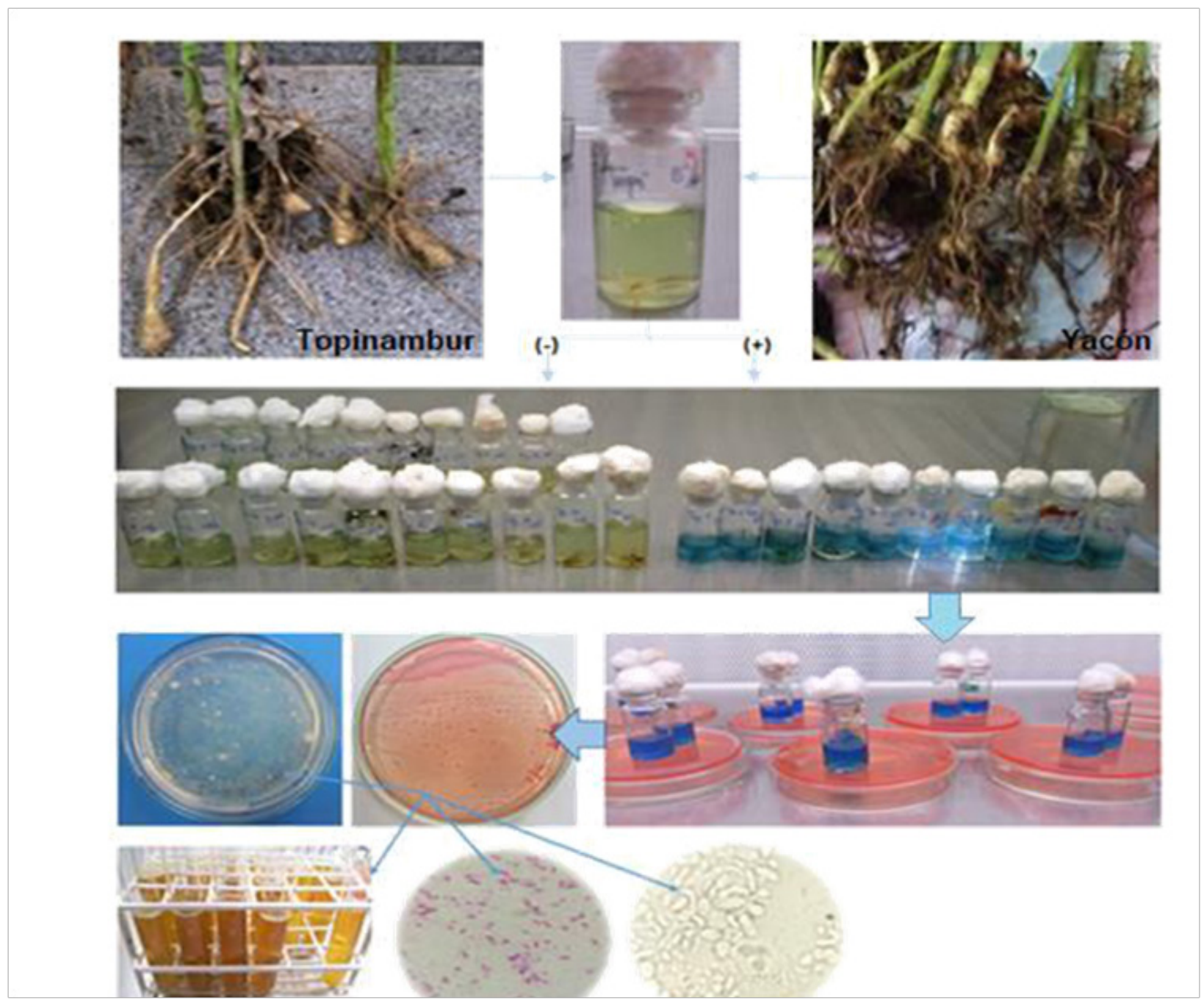

Figure I Isolation and characterization of endorrhizospheric FLN of topinambur and yacón. 


\section{Results and discussion}

Eleven bacterial isolates were obtained from all the root samples studied. Six of them came from the endorhizosphere of topinambur and five from that of yacón. Based on the different morphotypes obtained, 3 topinambur and 3 yacon isolates were sent to Macrogen (Korea) for molecular identification. Morphologically, most of the isolates presented small and mucoid colonies, and corresponded entirely to non-sporulated Gram negative bacilli (Table 1).

Analysis of the $16 \mathrm{~S}$ rRNA sequence determined that the molecularly identified bacteria belong to the genus Pseudomonas. Of the three isolates from the topinambur endorhizosphere, two of them corresponded to the P. sihuiensis species and the rest to Pseudomonas sp. In reference to the isolates obtained from yacón plants, they corresponded to the species Pseudomonas alcaligenes, P. resinovorans and P. sihuiensis (Table 1) (Figure 2).

Pseudomonas It is a genus of gram-negative aerobic gammaproteobacteria, belonging to the Pseudomonadaceae family that contains 191 described species. ${ }^{39}$ Members of the genus demonstrate great metabolic diversity and, consequently, are capable of colonizing a wide range of niches. ${ }^{40}$

Table I Molecular characterization and identification of the different isolates of $\mathrm{N}$-fixing bacteria obtained from the endorhizosphere of topinambur and yacón cultures.

\begin{tabular}{|c|c|c|c|c|}
\hline Crop & Isolated & Characterization colony morphology & $\begin{array}{l}\text { Characterization } \\
\text { biochemistry }\end{array}$ & $\begin{array}{l}\text { I6S rRNA gene } \% \\
\text { identity }\end{array}$ \\
\hline \multirow{11}{*}{$\begin{array}{l}\text { ऐ } \\
\text { है } \\
\text { है } \\
\text { है }\end{array}$} & Topil & $\begin{array}{l}\text { Red microcolonies and creamy in RC medium. } \\
\text { Bacilli G (-), no esporulated }\end{array}$ & $\begin{array}{l}\text { Aerobic, mobile, glucose (-), } \\
\text { lactose }(-) \text {. }\end{array}$ & $\begin{array}{l}\text { Pseudomonas sihuiensis } \\
99\end{array}$ \\
\hline & Topil A & $\begin{array}{l}\text { Yellowish microcolonies and mucosa in RC medium. } \\
\text { Bacilli G (-), no esporulated }\end{array}$ & $\begin{array}{l}\text { Aerobic, mobile, glucose }(+) \text {, } \\
\text { lactose }(-) \text {. }\end{array}$ & Pseudomonas sp. \\
\hline & Topi3 & $\begin{array}{l}\text { Orange microcolonies and creamy in RC medium. } \\
\text { Bacilli G (-), no esporulated. }\end{array}$ & $\begin{array}{l}\text { Aerobic, mobile, glucose (-), } \\
\text { lactose (-). }\end{array}$ & $\begin{array}{l}\text { Pseudomonas sihuiensis } \\
99\end{array}$ \\
\hline & Topi5 & $\begin{array}{l}\text { Red microcolonies and creamy in RC medium. } \\
\text { Bacilli G (-), no esporulated. }\end{array}$ & $\begin{array}{l}\text { Aerobic, mobile, glucose (-), } \\
\text { lactose }(-) \text {. }\end{array}$ & - \\
\hline & Topi9 & $\begin{array}{l}\text { Red microcolonies and creamy in RC medium. } \\
\text { Bacilli G (-), no esporulated. }\end{array}$ & $\begin{array}{l}\text { Aerobic, mobile, glucose }(-) \text {, } \\
\text { lactose }(-) \text {. }\end{array}$ & - \\
\hline & Topil0 & $\begin{array}{l}\text { Red microcolonies and creamy in RC medium. } \\
\text { Bacilli G (-), no esporulated. }\end{array}$ & $\begin{array}{l}\text { Aerobic, mobile, glucose }(-) \text {, } \\
\text { lactose }(-) \text {. }\end{array}$ & - \\
\hline & Ya3 & $\begin{array}{l}\text { Red microcolonies and consistent in RC medium. } \\
\text { Bacilli G (-), no esporulated. }\end{array}$ & $\begin{array}{l}\text { Aerobic, mobile, glucose (-), } \\
\text { lactose (-). }\end{array}$ & $\begin{array}{l}\text { Pseudomonas alcaligenes } \\
99\end{array}$ \\
\hline & Ya6 & $\begin{array}{l}\text { Red microcolonies and creamy in RC medium. } \\
\text { Bacilli G (-), no esporulated. }\end{array}$ & $\begin{array}{l}\text { Aerobic, mobile, glucose (-), } \\
\text { lactose (-). }\end{array}$ & - \\
\hline & Yall I & $\begin{array}{l}\text { Red microcolonies and fluid in RC medium. Bacilli G } \\
(-) \text {, no esporulated. }\end{array}$ & $\begin{array}{l}\text { Aerobic, mobile, glucose }(-) \text {, } \\
\text { lactose }(-) \text {. }\end{array}$ & $\begin{array}{l}\text { Pseudomonas } \\
\text { resinovorans }\end{array}$ \\
\hline & & & & 99 \\
\hline & Yal5 & $\begin{array}{l}\text { Red microcolonies and creamy in RC medium. } \\
\text { Bacilli G (-), no esporulated. }\end{array}$ & $\begin{array}{l}\text { Aerobic, mobile, glucose }(-) \text {, } \\
\text { lactose }(-) \text {. }\end{array}$ & - \\
\hline ర్ర్ర & YaMi & $\begin{array}{l}\text { Red microcolonies and creamy in RC medium. } \\
\text { Bacilli G (-), no esporulated. }\end{array}$ & $\begin{array}{l}\text { Aerobic, mobile, glucose (-), } \\
\text { lactose (-). }\end{array}$ & $\begin{array}{l}\text { Pseudomonas sihuiensis } \\
99\end{array}$ \\
\hline
\end{tabular}

Different species of the genus Pseudomonas are used in the manufacture of biofertizers not only as FBN, but also as phosphorus solubilizers, PGPR, and mobilizers of zinc and potassium. ${ }^{6}$ However, the molecularly identified isolates correspond to microorganisms reported in other countries and studied in the bioremediation of soils and waters contaminated by their ability to biodegrade hydrocarbons, pesticides and certain chemical substances, ${ }^{41-44}$ but without agricultural relevance. Such as, P. sihuiensis was isolated from forest soils of southern China ${ }^{45}$ and in Brazil in sites with a history of frequent oil spills ${ }^{46}$ and studied for its ability to biodegrade hydrocarbons in seawater and its application in the bioremediation of marine environments due to oil spills ${ }^{46}$ Furthermore, P. alcaligenes is used in antibacterial tests with the aim of evaluating the antimicrobial properties of oils essential substances ${ }^{47}$ antagonistic activity against plant pathogens. ${ }^{48}$ While, P. resinovorans studied to know gene transcription mechanisms and enzymatic activity, ${ }^{41,49,50}$ it can be a human pathogen, but the cases are very rare (Figure 3). ${ }^{51,52}$ 


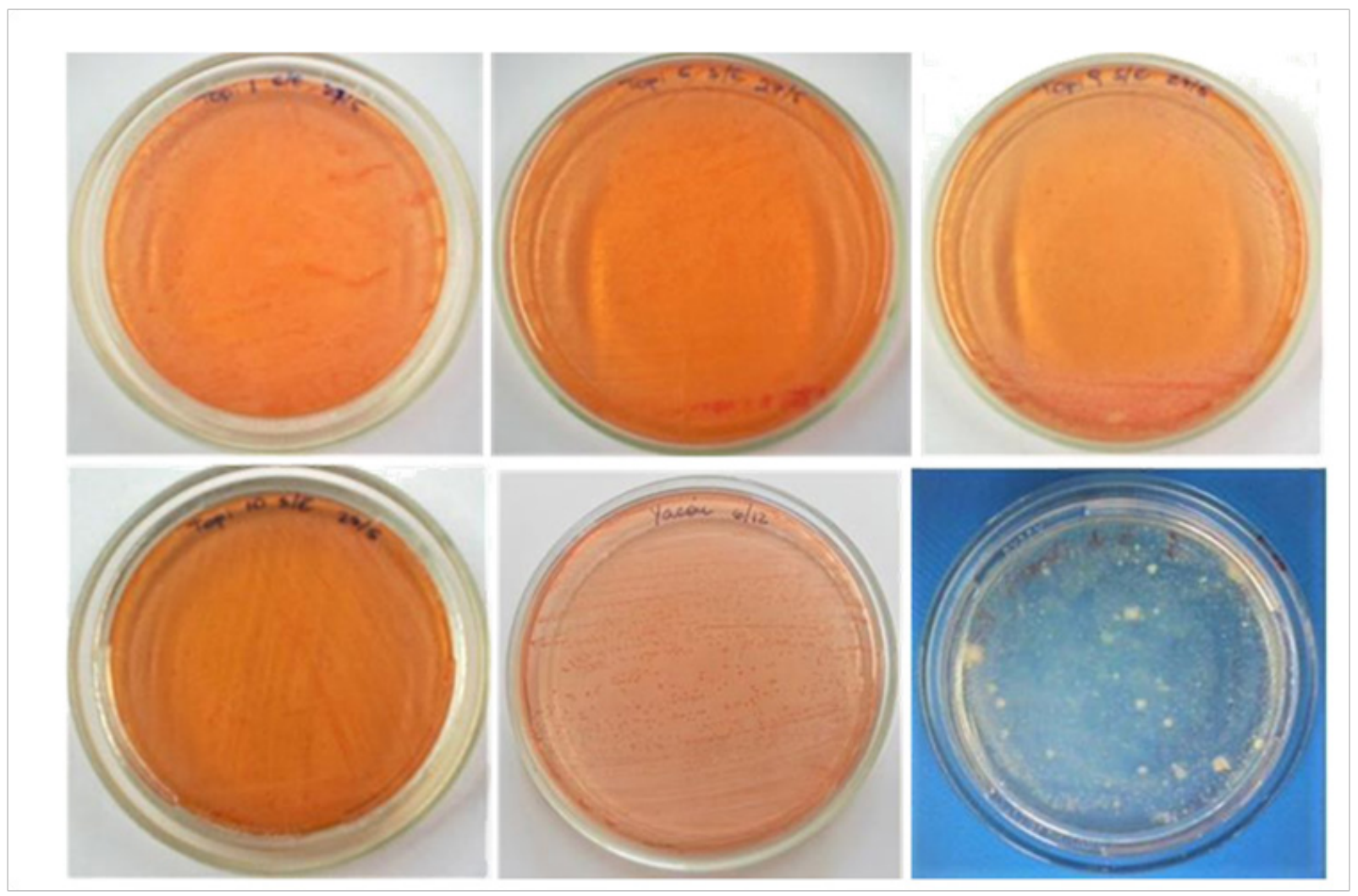

Figure 2 Colonies of nitrogen-free fixing bacteria from the endorhizosphere of topinambur (Helianthus tuberosus) and yacón (Smallanthus sonchifolius).

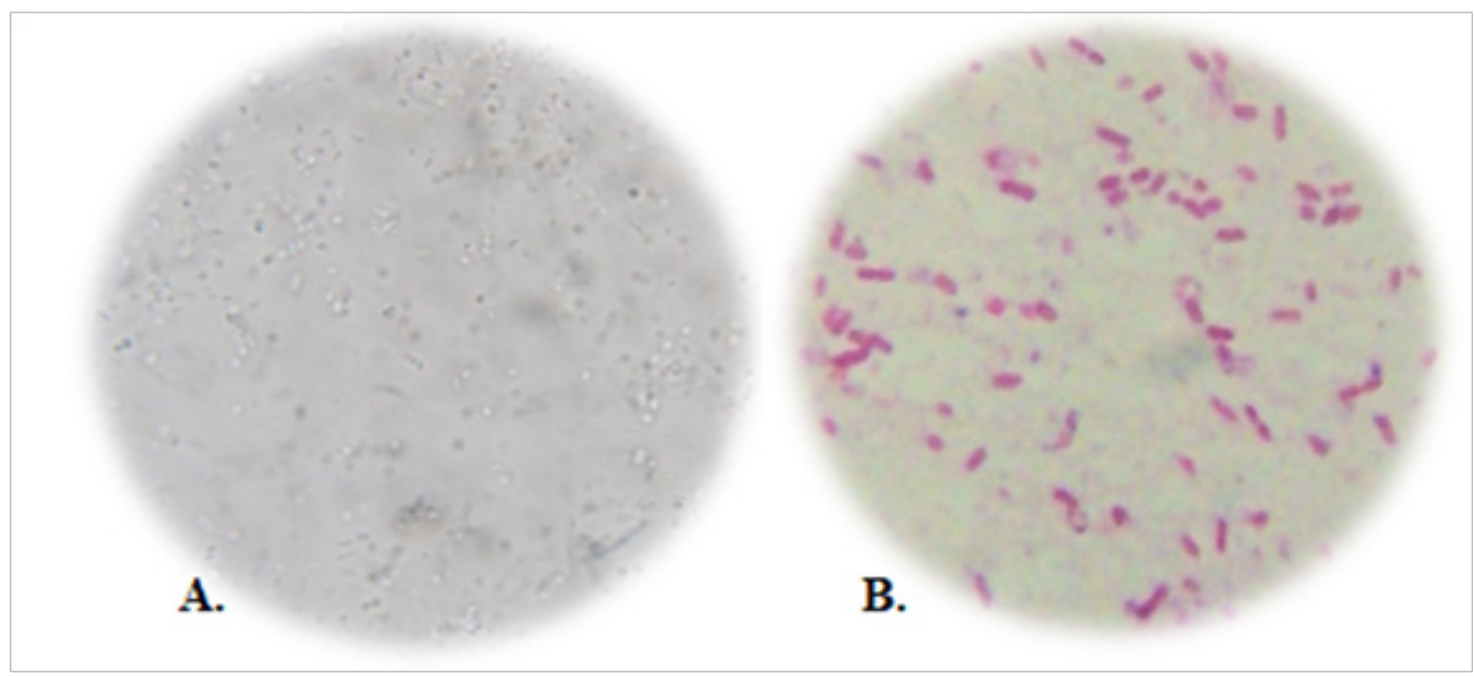

Figure 3 Photomicrographs of FLN bacteria from the endorhinosphere of topinambur (A: Prepared fresh) and yacón (B: Gram Nicolle staining). (A: 100x).

\section{Conclusion}

The investigation indicated the presence of bacteria of the Pseudomonas genus as free fixatives of atmospheric nitrogen in the endorhizosphere of topinambur and yacon grown in soils of the Central Valley of the Province of Catamarca. The species Pseudomonas sihuiensis, P. alcaligenes and P. resinovorans are reported for the first time in the province of Catamarca.

\section{Acknowledgments}

None.

\section{Conflicts of interest}

Authors declare no conflict of interestexists 


\section{References}

1. Döbereiner J, Baldani VLD, Baldani JI. How to isolate and identify diazotrophic bacteria from leguminous ñao plants. Brasília: EMBRAPASPI. Itaguaí, RJ. EMBRAPA-CNPAB. 1995;11-60.

2. Martín Alonso GM, Tamayo Aguilar Y, Hernández Forte I, et al Quantification of the biological fixation of nitrogen in Canavalia ensiformis grown in a soft brown carbonated soil using the methods of natural abundance offifteenN and total N difference. Cult Trop. 2017.

3. Calderoni PA. Analysis of populations of soil nitrogen fixing microorganisms applying metagenomic procedures. $\mathrm{PhD}$ thesis. Fac. Of Cs. Exactly. National University of La Plata. 2016;228.

4. Mayz-Figueroa J. Biological fixation of nitrogen. Rev UDO Agríc 2004;4(1):1-20.

5. Ibarra Sánchez CL. Diversity of nitrogen-fixing bacteria isolated from Chinampa soil and their effect on plants of agricultural interest. Master's Thesis. National Polytechnic Institute. Mexico. 2010;85.

6. Afanador Barajas LN. Biofertilizers: concepts, benefits and application in Colombia. Engineering. 2017;2(1):65-76.

7. Aguilar Borja MB. Selection of free-living bacteria efficient in biologica nitrogen fixation as a sustainable alternative for terrestrial ecosystems Food Science and Engineering Fac. Univ. Tec. Of Ambato. Ecuador. $2015 ; 149$.

8. Mansilla R, López C, Flores M, et al. Reproductive biology studies in five accessions of Smallanthus sonchifolius (Poepp. \& Endl.) Robinson. Applied Ecology, Univ Nac. Agraria La Molina, Lima-Peru. 2010;9(2):167-175

9. Manrique I, Parraga A, Hermann M. Yacon syrup: Principles and processing (8B). Conservation and use of Andean root and tuber biodiversity: A decade of research for development (1993-2003). International Potato Center. Lima Peru. 2005;31.

10. Yan MR, Welch R, Rush EC, et al. A sustainable wholesome foodstu; Health E_ects and potential dietotherapy applications of Yacon. Nutrients. 2019;11:2632:16.

11. Pacheco MT, Escribano-Bailón MT, Moreno FJ, et al. Determination by HPLC-DAD-ESI / MSn of phenolic compounds in Andean tubers grown in Ecuador. J Food Comp \& Anal. 2019;84:103258;9.

12. Satoh H, Audrey Nguyen MT, Kudoh A, et al. Yacon diet (Smallanthus sonchifolius, Asteraceae) improves hepatic insulin resistance via reducing Trb3 expression in Zucker fa / fa rats. Nutrit Diabetes. 2013;3:1-6.

13. Adriano LS, Dionysus AP, Pinto de Abreu FA, et al. Yacon syrup reduces postprandial glycemic response to breakfast: A randomized, crossover, double-blind clinical trial. Food Res. Intern. 2019;126:108682;8.

14. Tesio F, Vidotto F, Ferrero A. Allelopathic persistence of Helianthus tuberosus L. residues in the soil. Sci Hort. 2012.

15. Willscher S, Jablonski L, Fona Z, et al. Phytoremediation experiments with Helianthus tuberosus under different $\mathrm{pH}$ and heavy metal soil concentrations. Hydrometal. 2017;168:153-58.

16. Klímek P, Meinlschmidt $\mathrm{P}$, Wimmer $\mathrm{R}$, et al. Using sunflower (Helianthus annuus L.), topinambour (Helianthus tuberosus L.) and cupplant (Silphium perfoliatum L.) stalks as alternative raw materials for particleboards. Ind Crops \& Produc. 2016;92(15):157-164.

17. Bach V, Clausen MR, Edelenbos M. Production of Jerusalem Artichoke (Helianthus tuberosus L.) and Impact on Inulin and Phenolic Compounds. Processing and Impact on Active Components in Food. chap. 12.2015.

18. Gedrovica I, Karklina D, Fras A, et al. The non-starch polysaccharides quantity changes in pastry products where Jerusalem artichoke (Helianthus tuberosus L.) added. Procedia Food Sci. 2011;1:1638-1644.

19. Terzic S, Atlagic J, Maksimovic I, et al. Genetic variability for concentrations of essential elements in tubers and leaves of Jerusalem artichoke (Helianthus tuberosus L.). Sci Hort. 2012.

20. Sun PC, Liu Y, Yi YT, et al. Preliminary enrichment and separation of chlorogenic acid from Helianthus tuberosus L. leaves extract by macroporous resins. Food Chem. 2015;168:55-62.

21. Jeong GT. Catalytic conversion of Helianthus tuberosus L. to sugars, 5-hydroxymethylfurfural and levulinic acid using hydrothermal reaction. Biom \& Bioen. 2015.

22. Kim MJ, Dong-Ju An, Ki-Beom Moon, et al. Highly efficient plant regeneration and Agrobacterium-mediated transformation of Helianthus tuberosus L. Ind Crops \& Prod. 2016.

23. Okada N, Kobayashi S, Moriyama K, et al. Helianthus tuberosus (Jerusalem artichoke) tubers improve glucose tolerance and hepatic lipid profile in rats fed a high-fat diet. Asian Pacific J Trop Medic. 2017;439443

24. Judprasong K, Archeepsudcharit N, Chantapiriyapoon K, et al. Nutrients and natural toxic substances in commonly consumed Jerusalem artichoke (Helianthus tuberosus L.) tuber. Food Chem. 2018;238(1):173-179.

25. Kantar MB, Betts K, Michno JM, et al. Evaluating an interspecific Helianthus annuus $\times$ Helianthus tuberosus population for use in a perennial sunflower breeding program. Field Crops Res. 2014;155:254 264.

26. Ly J. Nitrogen and energy balance in pigs fed jerusalem artichokes (Helianthus tuberosus L.). Rev Comput Produc. 2011;7(3):32-38.

27. Volpini-Rapina LF, Ruriko Sokei F, Conti-Silva AC. Sensory profile and preference mapping of orange cakes with addition of prebiotics inulin and oligofructose. LWT - Food Sci. \& Technol. 2012;48:37-42.

28. Rossi R, Chicahuala MS. Productive evaluation of topinambur (Helianthus tuberosus L.) under different densities and fertilization in the central semiarid of Argentina. Hort Argent. 2017;36(90):49-58.

29. Roque J. Factsheet: Yacón botanical data. Smallanthus sonchifolius (Poepp.) H. Rob. First edition. Lima Peru. 2009.

30. Arnao I, Seminar J, Cisneros R, et al. Antioxidant potential of 10 yacon accessions, Smallanthus sonchifolius (Poepp. \& Endl.) H. Robinson, from Cajamarca - Peru. Annals of the Fac of Medicine. 2011;7(4):239243

31. Lachman J, Havrland B, Fernández EC, et al. Saccharides of yacon [Smallanthus sonchifolius (Poepp. Et Endl.) H. Robinson] tubers and rhizomes and factors affecting their content. Plant Soil Environ. 2004;(9):383-390

32. Fernández EC, Viehmannová I, Lachman J, et al. Yacon [Smallanthus sonchifolius (Poeppig \& Endlicher) H. Robinson]: a new crop in the Central Europe. Plant Soil Environ. 2006;52(12):564-570.

33. Santana I, Cardoso MH. Tuberous root of yacon (Smallanthus sonchifolius): cultivation potential, technological and nutritional aspects. Rural Science Sta Ma. 2008;38(3):898-905.

34. Muñoz Jáuregui AM. Monograph of the yacón Smallanthus sonchifolius (Poepp. \& Endl.). Perubiodiverse. Lima Peru. 2009.

35. Mercado MI, Coll AMV, Brandán de Weht CI, et al. Arbuscular mycorrhizal associations and dark septate endophytes in Yacon (Smallanthus sonchifolius) and a wild relative (Smallanthus macroscyphus). Bol Soc Argent Bot. 2013;48(2):193-200.

36. Tarrand JJ, Krieg NR, Döbereiner J. A taxonomic study of the Spirillum 
lipoferum group, with descriptions of a new genus, Azospirillum gen Nov. and two species, Azospirillum lipoferum (Beijerinck) comb. Nov. and Azospirillum brasilense sp. Nov Dog J Microbiol. 1978;24(8):967980.

37. Holt JG, Kreig NR, Sneath PH, et al. Bergey's manual of determinative bacteriology, 9th baltimore: williams and wilkins Company. 1994.

38. Buchanan RE, Gibbonns NE. Bergey's manual of determinative bacteriology, 9th Baltimore: Williams \& Wilkins Company. 1994.

39. Peix A, Ramírez-Bahena MH, Velázquez E. Review: The current status on the taxonomy of Pseudomonas revisited: An update. Infec Genetics \& Evol. 2018;57:106-116.

40. Cutiño-Jiménez AM, Peña Cutiño HA. Insertions in protein sequences for the taxonomy and phylogeny of the families Pseudomonadaceae and Moraxellaceae (Order Pseudomonadales). Rev CENIC Cienc Biol. 2019;50(2):143-157.

41. Nojiri H, Maeda K, Sekiguchi H, et al. Organization and transcriptional characterization of catecholdegradation genes involved in carbazole degradation by pseudomonasresinovorans strain CA10. Biosci Biotechnol. \& Biochem. 2002;66(4):897-901.

42. Widada J, Nojiri H, Yoshida T, et al. Enhanced degradation of carbazole and 2,3-dichlorodibenzo-p-dioxin in soils by Pseudomonas resinovorans strain CA10. Chemosphere. 2002;49(5):485-491.

43. O'Mahony MM, Dobson AD, Barnes JD, et al. The use of ozone in theremediation of polycyclic aromatic hydrocarbon contaminated soil. Chemosphere. 2006;63(2):307-314.

44. Yang CF, read CM. Enrichment, isolation, and characterization of phenoldegrading Pseudomonas resinovorans strain P-1 and Brevibacillus sp. strain P-6.Intern. Biodet \& Biodeg. 2007.
45. Wu M, Wen J, Chang M, et al. Pseudomonas sihuiensis sp. Nov., isolated from a forest soil in South China. A. van Leeuwenhoek 2014.

46. Pereira E, Napp AP, Allebrandt, et al. Biodegradation of aliphatic and polycyclic aromatic hydrocarbons in seawater by autochthonous microorganisms. Intern.Biodet \& Biodeg. 2019:145.

47. Kaczorek E. Effect of external addition of rhamnolipids biosurfactant on the modification of Gram positive and Gramnegative bacteria cell surfaces during biodegradation of hydrocarbon fuel contamination. Pol J Environ. Stud. 2012;21(4):901-909.

48. Widnyana IK, Suprapta DN, Sudana IM, et al. Pseudomonas alcaligenes, potential antagonist against fusarium oxysporum $\mathrm{f}$. sp. lycopersicum the cause of fusarium wilt disease on tomato. J Biol Agric \& Healthcare. 2013;3(7):163-169.

49. Takagi T, Nojiri H, Yoshida T, et al. Detailed comparison between the substrate specificities of two angular dioxygenases, dibenzofuran 4.4a-dioxygenase from Terrabacter sp. and carbazole 1,9a-dioxygenase from Pseudomonas resinovorans. Biotechnol Lett. 2002.

50. Nam JW, Noguchi H, Fujimoto Z, et al. Crystal structure of the ferredoxin component of carbazole 1,9a- dioxygenase of Pseudomonas resinovorans strain CA10, a novel Rieske non - hemeiron oxygenase system. Proteins. 2005;58(4):779-789.

51. Suzuki Masato, Suzuki Satowa, Matsui Mari, et al. Genome sequence of a strain of the human pathogenic bacterium pseudomonas alcaligenes that caused bloodstream infection. Genome Announc. 2013;1(5).

52. Slim GT, Tamashiro WM, Maróstica Junior M, et al. Yacon (Smallanthus sonchifolius): a functional food. Planting Hum Nutr food. 2013. 